\title{
Early Sowing of Grain Legume Crops after Rice Harvest Increases Grain Yield
}

\author{
Marcal Gusmao \\ Department of Agronomy and Centre for Climate Change and Biodiversity, Faculty of Agriculture, \\ National University of Timor Lorosa'e, Timor-Leste
}

Copyright $(2018$ by authors, all rights reserved. Authors agree that this article remains permanently open access under the terms of the Creative Commons Attribution License 4.0 International License

\begin{abstract}
Most paddy fields in Timor Leste are abandoned after harvesting the rice crop due to limited supplemental irrigation. Other field studies have identified some drought-adaptive grain legumes including kidney bean (previously grown in cold, highland areas only), Ceora grass pea (Lathyrus sativus L., a newly introduced species), mung bean, and soybean for growing after rice harvest. The impact of sowing date on growth and yield after rice harvest is not well understood. The current study aimed to identify the appropriate sowing time of grain legumes after rice harvest. Seeds of kidney bean and grass pea were sown in plots arranged in a randomized block design with three factors (species, drought treatment, and sowing date) and three replications. There were three sowing dates at monthly intervals: 28 May (D1), 28 June (D2) and 28 July 2017 (D3). The terminal drought treatment was applied at first flower of grass pea or pod set of kidney bean for each sowing date. Overall, kidney bean produced more seed yield (32\% higher) than grass pea. Yields of both species decreased at the later sowing dates $(\mathrm{P}<0.001)$. Grass pea produced $78 \%$ more filled pods than kidney bean, but $34 \%$ fewer seeds per pod and $58 \%$ smaller seeds than kidney bean. Seed weight in both species decreased at later sowing dates as did seeds per pod in kidney bean, but grass pea maintained seed numbers per pod at all sowing dates. Dry matter production between species was comparable, which declined at later sowing dates $(\mathrm{P}<0.001)$. In conclusion, early sowing of grain legumes produces more seeds and biomass after rice harvest than late sowing.
\end{abstract}

Keywords Paddy Field, Grain Legumes, Grass Pea, Kidney Bean, Sowing Dates, Terminal Drought, Yield

\section{Introduction}

Most paddy fields in Timor Leste are abandoned after rice harvesting due to limited supplemental irrigation.
Other field studies have identified potential drought-adapted grain legumes including kidney bean, grass pea, mung bean, cowpea and soybean for cropping after rice harvest (Gusmao, 2016, 2017). Gusmao (2017) reported the adaptation of kidney bean (previously grown in cold, highland areas only) and grass pea (Lathyrus sativus) to new production environments. The study concluded that kidney bean, with its determinant growth habit, could be grown in lowland, coastal areas during the dry season. Cultivars Ceora and Cicera of grass pea (Lathyrus sativus), with indeterminant growth habits, are new to Timor Leste (introduced by Dr. Marcal Gusmao from Australia) and reportedly well-adapted to this environment (Gusmao, 2016, 2017). However, Cicera is reportedly adapted to the highlands only, while Ceora which was developed at the Centre for Legumes in Mediterranean Agriculture (CLIMA) at the University of Western Australia (Siddique et al., 2006) is adapted to both the highlands and lowland, coastal areas. Kidney bean and grass pea have the potential to grow using the residual water in the paddy field for grain production after rice harvest. The appropriate sowing time for grain legumes after rice is not well understood but is important for maximizing grain yield after rice harvest. Thus, identifying the appropriate sowing time for grain legumes would help to manage rice sowing dates and thus harvest.

\section{Research Objectives}

This study aimed to identify the impact of sowing date on growth and yield of kidney bean and grass pea cultivar Ceora and the appropriate sowing date of the grain legumes after rice harvest.

\section{Research Methods}

\section{Research Design, Site, Land Preparation}

The study was conducted in a horticultural area of 
Manleuana (previous rice production area), Dili, Timor Leste using a randomized block design with three factors (species, drought treatment, and sowing date) and three replications.

The land was prepared in May 2017 to create 12 plots (each $180 \times 140 \mathrm{~cm}$ ) for each of the four sowing dates (detail below).

\section{Sowing}

Two grain legumes-kidney bean and grass pea (Lathyrus sativus $\mathrm{cv}$. Ceora) - were used in this study. The kidney bean seeds came from a local farmer in the Quelicai highland, Baucau Municipality and represented a determinate growth habit species. The Ceora seeds came from previous trials in Timor Leste (Gusmao, 2016, 2017) - as the species had been recently introduced by Dr. Marcal Gusmao from Australia-and represented an indeterminate growth habit species. The kidney bean and grass pea seeds were sown at monthly intervals on 28 May (D1), 28 June (D2), 28 July (D3), and 28 August (D4) 2017. Sowing at D4, however, did not produce any yield due to damage from the onset of rain and was not included in the results. For each sowing date, three kidney bean seeds were sown in each hole and thinned to two seedlings per hole when established. The grass pea seeds were germinated first (on the same sowing dates) with two plants transplanted into each hole when the seedlings were well-established. The planting distances were $25 \mathrm{~cm}$ by 20 $\mathrm{cm}$ in both species.

\section{Watering and Drought Treatment}

Plots were watered using hand sprayer, a day before sowing of seeds, to bring the soil moisture to approximately field capacity. Watering continued regularly until the reproductive stage where terminal drought was initiated. The terminal drought applied to both species at the same time at which kidney bean plant was at its podding stage, while grass pea was at its first flowering stage. The control plants were well-watered until maturity.

\section{Yield and Yield Component Measurements}

Plants were harvested when they reached $90-100 \%$ physiological maturity. Eighteen above ground plants were harvested from a $50 \times 40 \mathrm{~cm}$ area $\left(0.20 \mathrm{~m}^{2}\right)$ within each plot. Five of the 18 plants were randomly selected for measurements including numbers of plant nodes, branches, filled pods, empty pods and seeds per pod, and plant height. The seeds were separated from the pods and counted. The pod walls were added to the other plant components and oven dried at $75^{\circ} \mathrm{C}$ for $48 \mathrm{~h}$ before being weighed. The seeds remained in the oven for a few more hours to ensure that they were well-dried before being weighed. One hundred seeds were randomly selected and weighed for seed size determination. The total seed dry weight was summed with the plant dry weight to obtain total aboveground dry matter production.

\section{Analysis}

The data were analyzed using the statistical package of Genstat 10 to compare growth and yield between species, sowing dates, and drought treatments.

\section{Results}

There were no three-way interactions of Species*Treatment*Date, except for seed weight (Fig. 1). There were many two-way interactions of Species*Date in the parameters measured (Tables 1 and 2). In general, grass pea produced 158.4 more plant nodes (170.5 nodes) than kidney bean (12.1 nodes) $(\mathrm{P}<0.001)$ (Table 1). The number of plant nodes declined at later sowing dates (by $36 \%$ and $45 \%$ for $\mathrm{D} 2$ and $\mathrm{D} 3$, respectively, relative to $\mathrm{D} 1)(\mathrm{P}<0.001)$. Grass pea plants were $14.5 \mathrm{~cm}$ taller $(38.06 \mathrm{~cm})$ than kidney bean plants $(23.58 \mathrm{~cm})(\mathrm{P}<0.001)$. Plant height declined by $26 \%$ and $30 \%$ for $\mathrm{D} 2$ and $\mathrm{D} 3$, respectively, relative to $\mathrm{D} 1(\mathrm{P}<0.001)$. Drought reduced plant height by $4 \mathrm{~cm}$ compared to the control plants $(\mathrm{P}=0.009)$. Grass pea also produced 12.5 more branches (16.41 branches) than kidney bean ( 3.91 branches) $(\mathrm{P}<0.001)$. Unlike the other parameters, branch number increased by $11 \%$ for $\mathrm{D} 2$, but declined by $33 \%$ for $\mathrm{D} 3$, relative to $\mathrm{D} 1(\mathrm{P}=0.005)$. Grass pea produced 17 more pods with seeds (filled pods) than kidney bean $(\mathrm{P}<0.001)$. The number of filled pods declined by $38 \%$ and $73 \%$ for $\mathrm{D} 2$ and $\mathrm{D} 3$, respectively, relative to $\mathrm{D} 1(\mathrm{P}<0.001)$. Grass pea had about nine more empty pods than kidney bean $(\mathrm{P}<0.001)$. The number of empty pods decreased by $44 \%$ and $58 \%$ for D2 and D3, respectively, relative to $\mathrm{D} 1(\mathrm{P}<0.001)$. Grass pea produced 0.8 fewer seeds per pod than kidney bean $(\mathrm{P}<0.001)$. There was no treatment or date impact on the number of seeds/pod in either species. Grass pea produced lighter seeds (by 13 g/100 seeds) than kidney bean (Table 2). Seed weight declined for D2 and D3 by $17 \%$ and $36 \%$, respectively, relative to D1. Grass pea produced $33 \%$ less seed yield than kidney bean $(\mathrm{P}=0.009)$. The seed yield declined by $32 \%$ and $63 \%$ for D2 and D3, respectively, relative to D1 $(\mathrm{P}<0.001)$. There were no differences in dry matter production between the species $(\mathrm{P}=0.294)$. Dry matter production declined by $25 \%$ and $52 \%$ for $\mathrm{D} 2$ and $\mathrm{D} 3$, respectively, relative to $\mathrm{D} 1(\mathrm{P}<0.001)$. Terminal drought reduced dry matter production by $24 \%$ compared to control plants. 


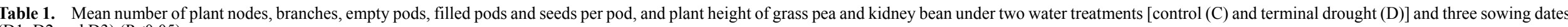
(D1, D2 and D3) $(\mathrm{P}<0.05)$.

\begin{tabular}{|c|c|c|c|c|c|c|c|c|c|c|c|c|c|c|c|c|c|c|c|}
\hline \multirow{2}{*}{ Species } & \multirow{2}{*}{$\begin{array}{c}\text { Water } \\
\text { treatment }\end{array}$} & \multicolumn{3}{|c|}{ Node no } & \multicolumn{3}{|c|}{ Plant height, $\mathrm{cm}$} & \multicolumn{3}{|c|}{ No of branches } & \multicolumn{3}{|c|}{ No of empty pods } & \multicolumn{3}{|c|}{ No of filled pods } & \multicolumn{3}{|c|}{ Seed/pod } \\
\hline & & D1 & D2 & D3 & D1 & D2 & D3 & D1 & D2 & D3 & D1 & D2 & D3 & D1 & D2 & D3 & D1 & D2 & D3 \\
\hline \multirow[t]{2}{*}{ Grass pea } & $\mathrm{C}$ & 239.7 & 135.0 & 153.7 & 52.3 & 32.7 & 40.3 & 16.2 & 21.5 & 14.0 & 12.5 & 6.5 & 6.7 & 42.7 & 22.5 & 9.9 & 1.5 & 1.6 & 1.4 \\
\hline & D & 229.9 & 163.3 & 101.2 & 39.8 & 31.3 & 31.9 & 18.4 & 20.1 & 8.3 & 18.7 & 10.1 & 5.6 & 31.1 & 20.5 & 5.2 & 1.4 & 1.6 & 1.5 \\
\hline \multirow[t]{2}{*}{ Kidney bean } & $\mathrm{C}$ & 16.8 & 10.9 & 11.0 & 28.9 & 27.4 & 17.9 & 4.1 & 3.9 & 3.8 & 5.9 & 1.5 & 1.0 & 5.9 & 5.9 & 3.9 & 2.6 & 2.4 & 2.0 \\
\hline & $\mathrm{D}$ & 14.1 & 10.4 & 9.3 & 30.4 & 20.9 & 15.9 & 4.9 & 3.5 & 3.3 & 5.3 & 1.3 & 1.2 & 5.3 & 4.1 & 4.1 & 2.3 & 2.3 & 2.0 \\
\hline \multicolumn{20}{|c|}{ LSD- } \\
\hline \multicolumn{2}{|c|}{ Species } & \multicolumn{3}{|c|}{$22.89 * * *$} & \multicolumn{3}{|c|}{$3.560 * * *$} & \multicolumn{3}{|c|}{$2.347 * * *$} & \multicolumn{3}{|c|}{$1.770 * * *$} & \multicolumn{3}{|c|}{$3.755^{* * *}$} & \multicolumn{3}{|c|}{$0.1899 * * *$} \\
\hline \multicolumn{2}{|c|}{ Treatment } & \multicolumn{3}{|c|}{$22.89 \mathrm{~ns}$} & \multicolumn{3}{|c|}{$3.560^{* *}$} & \multicolumn{3}{|c|}{$2.347 \mathrm{~ns}$} & \multicolumn{3}{|c|}{$1.770 \mathrm{~ns}$} & \multicolumn{3}{|c|}{$3.755 \mathrm{~ns}$} & \multicolumn{3}{|c|}{$0.1899 \mathrm{~ns}$} \\
\hline \multicolumn{2}{|c|}{ Date } & \multicolumn{3}{|c|}{$28.03 * * *$} & \multicolumn{3}{|c|}{$4.360^{* * *}$} & \multicolumn{3}{|c|}{$2.874^{* *}$} & \multicolumn{3}{|c|}{$2.167 * * *$} & \multicolumn{3}{|c|}{$4.599 * * *$} & \multicolumn{3}{|c|}{$0.2326 \mathrm{~ns}$} \\
\hline Species & eatment & & & & & & & & & & & 2.5 & & & 5.3 & & & 0.2 & \\
\hline Spec & Date & & 39. & & & & & & & & & 3.06 & & & 6.50 & & & 0.3 & Ons \\
\hline Treatı & *Date & & & & & & & & & & & 3.0 & & & 6.5 & & & 0.3 & \\
\hline Species*T & nent*Date & & 56. & & & & & & & & & 4.3 & & & 9.1 & & & 0.4 & $3 \mathrm{~ns}$ \\
\hline
\end{tabular}

*** significant at $\mathrm{P} \leq 0.001, * *$ significant at $\mathrm{P} \leq 0.01$, * significant at $\mathrm{P} \leq 0.05$, ns not significantly different

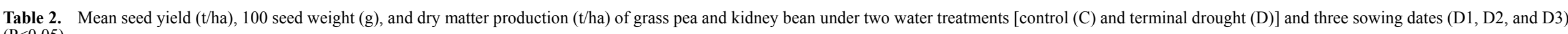

\begin{tabular}{|c|c|c|c|c|c|c|c|c|c|c|}
\hline \multirow{2}{*}{ Species } & \multirow{2}{*}{$\begin{array}{l}\text { Water } \\
\text { treatment }\end{array}$} & \multicolumn{3}{|c|}{ Seed yield (t/ha) } & \multicolumn{3}{|c|}{100 seed weight $(\mathrm{g})$} & \multicolumn{3}{|c|}{ Dry matter (t/ha) } \\
\hline & & D1 & D2 & D3 & D1 & D2 & D3 & D1 & D2 & D3 \\
\hline \multirow[t]{2}{*}{ Grass pea } & $\mathrm{C}$ & 1.3 & 0.8 & 0.3 & 10.5 & 10.3 & 9.2 & 3.6 & 2.8 & 1.9 \\
\hline & $\mathrm{D}$ & 0.9 & 0.5 & 0.1 & 10.2 & 10.0 & 5.3 & 2.6 & 1.7 & 0.8 \\
\hline \multirow[t]{2}{*}{ Kidney bean } & $\mathrm{C}$ & 1.5 & 1.2 & 0.1 & 27.9 & 21.8 & 12.6 & 3.6 & 3.1 & 1.2 \\
\hline & $\mathrm{D}$ & 1.1 & 0.7 & 1.0 & 27.2 & 20.5 & 21.7 & 3.0 & 1.9 & 2.3 \\
\hline \multicolumn{11}{|l|}{ LSD- } \\
\hline \multicolumn{2}{|c|}{ Species } & \multicolumn{3}{|c|}{$0.2355 * *$} & \multicolumn{3}{|c|}{$1.728 * * *$} & \multicolumn{3}{|c|}{$0.513 \mathrm{~ns}$} \\
\hline \multicolumn{2}{|c|}{ Treatment } & \multicolumn{3}{|c|}{$0.2355 \mathrm{~ns}$} & \multicolumn{3}{|c|}{$1.728 \mathrm{~ns}$} & \multicolumn{3}{|c|}{$0.513 *$} \\
\hline \multicolumn{2}{|c|}{ Date } & \multicolumn{3}{|c|}{$0.2885 * * *$} & \multicolumn{3}{|c|}{$2.116^{* * *}$} & \multicolumn{3}{|c|}{$0.629 * * *$} \\
\hline \multicolumn{2}{|c|}{ Species*Treatment } & \multicolumn{3}{|c|}{$0.3331 \mathrm{~ns}$} & \multicolumn{3}{|c|}{$2.443^{*}$} & \multicolumn{3}{|c|}{$0.726 \mathrm{~ns}$} \\
\hline \multicolumn{2}{|c|}{ Species*Date } & \multicolumn{3}{|c|}{$0.4080 \mathrm{~ns}$} & \multicolumn{3}{|c|}{$2.993^{* *}$} & \multicolumn{3}{|c|}{$0.889 \mathrm{~ns}$} \\
\hline \multicolumn{2}{|c|}{ Treatment*Date } & \multicolumn{3}{|c|}{$0.4080^{*}$} & \multicolumn{3}{|c|}{$2.993 \mathrm{~ns}$} & \multicolumn{3}{|c|}{$0.889 \mathrm{~ns}$} \\
\hline \multicolumn{2}{|c|}{ Species*Treatment*Date } & \multicolumn{3}{|c|}{$0.5770 \mathrm{~ns}$} & \multicolumn{3}{|c|}{$4.232 * *$} & \multicolumn{3}{|c|}{$1.257 \mathrm{~ns}$} \\
\hline
\end{tabular}

\footnotetext{
*** significant at $\mathrm{P} \leq 0.001$, ** significant at $\mathrm{P} \leq 0.01$, *significant at $\mathrm{P} \leq 0.05$, ns not significantly different
} 


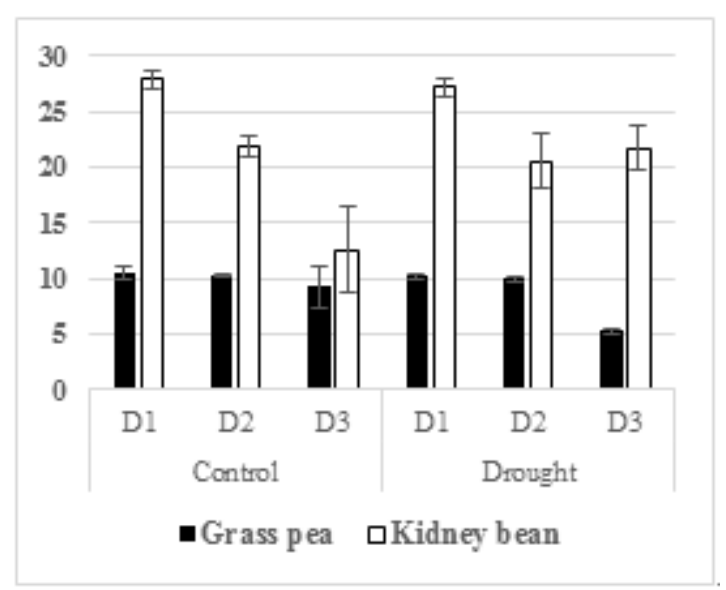

Figure 1. The interaction between species, treatment and date on 100 seed weight $(\mathrm{g})$ at $\mathrm{P}<0.003$

\section{Discussion}

Other studies have identified grain legumes that can be grown after rice harvest (Gusmao, 2016, 2017). The current study investigated an appropriate time for sowing grain legumes after rice harvest using kidney bean (determinate growth habit), which had previously been grown only in the highland areas of Timor Leste, and the newly introduced grass pea (Lathyrus sativus cv. Ceora; indeterminate growth habit) (Gusmao et al., 2012). Kidney bean has a short growth cycle of $\sim 72$ days, while grass pea has a long growth cycle of $\sim 115$ days to maturity (Gusmao, 2017). In the current study, terminal drought had little impact on the development or yield of grass pea or kidney bean as there was minimal impact on soil water content (data not shown) and this was partly due to rainfall interruption. In contrast, the species differed in their growth and yield responses to sowing date.

In general, grass pea produced 158 more plant nodes than kidney bean (Table 1). The high number of nodes in grass pea is consistent with other field study of up to 272 plant nodes (Gusmao, 2017). With no growth restriction, a single stem of grass pea can produce up to 38 nodes (Gusmao et al., 2012). In the current study, the number of plant nodes declined in both species with the delay in sowing date, more so in grass pea (46\%) than kidney bean (35\%) at D3 (July sowing), relative to D1 (May sowing). A reduction in the number of plant nodes was associated with reductions in plant height and branch number. Grass pea plants were $14.5 \mathrm{~cm}$ taller than kidney bean. Plant height declined in both species with the later sowing dates of June and July. Terminal drought reduced plant height by $4.9 \mathrm{~cm}$ relative to the control plants in both species. Grass pea produced 12.5 more branches than kidney bean. Between the dates number of branches increased slightly in D2 before declining in D3. On the other hand, branch number in kidney bean declined with the delay in sowing date.

Overall, grass pea produced more pods than kidney bean due to its higher numbers of plant nodes and branches, and taller plants. Grass pea produced 17 more filled pods than kidney bean. The number of filled pods in grass pea declined linearly from D1 to D2 to D3, while there was little change in kidney bean. Grass pea produced 8.6 more empty pods per plant than kidney bean. High empty pod numbers in grass pea have been reported in a greenhouse study (Gusmao et al., 2012) and the field (Gusmao, 2016, 2017). Empty pod numbers in grass pea also declined steadily from D1 to D2 to D3, while there was little change in kidney bean. The empty pod of kidney bean produced from current study was associated with less total pod production. When total pods produced increases, number of empty pods also goes up as shown in a greenhouse study (Gusmao, et al., 2012) and the field (Gusmao, 2016) and this may be associated with limited resources and competition among the pods (Gusmao et al., 2012).

Grass pea produced fewer seeds per pod and less seed weight than kidney bean, which resulted in lower seed yields. Grass pea had 0.8 fewer seeds per pod than kidney bean, with no differences between sowing dates or the terminal drought treatment. Interestingly, there was a three-way interaction between species, water treatment and sowing date on seed weight (Fig. 1). The 100-seed weight of grass pea was $12.7 \mathrm{~g}$ lower than kidney bean. Seed weight in grass pea changed little between sowing dates but declined at D3 in droughted plants. Sowing time at D3 was probably more responsible for low seed weight rather than the terminal drought. A greenhouse study reported the stability of seed size of grass pea under severe water deficit conditions during reproductive stage (Gusmao, et al., 2012). In contrast, seed weight in kidney bean declined steadily from D1 to D2 to D3, with a similar pattern in droughted plants, apart from a slight increase from D2 to D3. Similar seed weights between droughted and control plants have been reported elsewhere (Gusmao, 2016). The increased seed weight in droughted kidney bean suggests its adaptive response to water deficit as reported by Blum (1996) and Ludlow and Muchow (1990).

In general, this study produced lower grass pea and kidney bean yields than other field studies (Gusmao, 2016, 2017), ranging from $1.3 \mathrm{t} / \mathrm{ha}$ at $\mathrm{D} 1$ to $0.1 \mathrm{t} / \mathrm{ha}$ at $\mathrm{D} 3$ in grass pea and $1.5 \mathrm{t} / \mathrm{ha}$ at D1 to $0.3 \mathrm{t} / \mathrm{ha}$ at D3 in kidney bean compared with 2.8 and 2.0 t/ha for kidney bean and grass pea, respectively (Gusmao, 2017). In the current study, kidney bean yielded $0.3 \mathrm{t} / \mathrm{ha}$ more than grass pea, due to its higher seed number per pod and seed weight. Kidney bean had an advantage over grass pea due to its earlier maturity ( 72 days after sowing) (Gusmao, 2017), which could be associated with better yields particularly in water limited environment during the reproductive stage (Muchow, 1985; Leport et al. 1998; Ludlow and Muchow 1990; Siddique et al. 2001). In the current study, yields of both species steadily declined with the delay in sowing date, which was associated with fewer pod numbers and seeds per pod, and is consistent with a study on various grain legumes 
(Muchow, 1985). A reduction in seed weight and seed yield at later sowings in high land environments has been reported for common beans (Acosta-Gallegos et al., 1996).

Dry matter production did not differ between species, which is consistent with another study by Gusmao (2016), but steadily declined with the delay in sowing date. The terminal drought treatment reduced dry matter production in both species. When water deficit during the reproductive period is severe, a rapid growth and development of grain legumes is important. Remobilization of pre anthesis carbon and nitrogen during water deficit can support seed filling as reported in chickpeas (Davies et al., 1999; Davies et al., 2000).

\section{Conclusions}

Early sowing increased seed yield and biomass production in grass pea and kidney bean sown after rice harvest. Kidney bean had an advantage over grass pea with its higher seed yield and earlier maturity.

\section{Acknowledgements}

The research was funded by the Australian Alumni Small Grant Fund. I thank my field staff Domingos Pinto and field labor Belarmino da Costa and other temporary workers for their hard work during the research activities. I also thank Professor Kadambot Siddique for critical comments on the manuscript and language editing.

\section{REFERENCES}

[1] Acosta-Gallegos JA, Vargas-Vazquez P, White W (1996) Effect of sowing date on the growth and seed yield of common bean (Phaseolus vulgaris L.) in highland environments. Field Crops Research 49, 1-10.

[2] Blum A (1996) Crop responses to drought and the interpretation of adaptation. Plant Growth Regulation 20, $135-148$

[3] Davies SL, Turner NC, Siddique KHM, Plummer JA, Leport L (1999) Seed growth of desi and kabuli chickpea
(Cicer arietinum L.) in a short-season Mediterranean-type environment. Australian Journal of Experimental Agriculture 39, 181-188.

[4] Davies SL, Turner NC, Palta JA, Siddique KHM, Plummer JA (2000) Remobilisation of carbon and nitrogen supports seed filling in chickpea subjected to water deficit. Australian Journal of Agricultural Research 51, 855-866.

[5] Gusmao M (2017) Selection of drought resistance grain legumes for growing after rice. In: Proceedings of the "Timor-Leste Studies Association Conference", Dili, 29-30 June 2017, vol. 2, p. 143.

[6] Gusmao M (2016) Identification of drought resistance legume crop species for growing them after rice to improve food security in Timor-Leste (poster). Proceeding of the TimorAgri International Conference, 13-15 April 2016, Dili, and Timor-Leste.

[7] Gusmao M, Siddique KHM, Flower K, Nesbitt H, Veneklaas EJ (2012) Water deficit during reproductive period of grass pea (Lathyrus sativus L.) reduced seed yield but maintained seed size. Journal of Agronomy \& Crop Science 198, 430-441.

[8] Gusmao M (2010) Grass pea (Lathyrus sativus cv. Ceora) adaptation mechanisms of grass pea ( $L$. sativus $\mathrm{cv}$. Ceora) to water deficit conditions and benefit in crop rotation. $\mathrm{PhD}$ thesis, The University of Western Australia, Perth, WA, Australia.

[9] Leport L, Turner NC, French RJ, Tennant D, Thomson BD, Siddique KHM (1998) Water relations, gas exchange and growth of cool-season grain legumes in a Mediterranean-type environment. European Journal of Agronomy 9, 295-303.

[10] Ludlow and Muchow 1990; Ludlow MM, Muchow RC (1990) A critical evaluation of traits for improving crop yields in water-limited environments. Advances in Agronomy 43, 107-153.

[11] Muchow RC (1985) Phenology, seed yield and water use of grain legumes grown under different soil water regimes in a semi-arid tropical environment. Field Crops Research 11, 81-97.

[12] Siddique KHM, Regan KL, Tennant D, Thomson BD (2001) Water use and water use efficiency of cool season grain legumes in low rainfall Mediterranean-type environments. European Journal of Agronomy 15, 267-280.

[13] Siddique KHM, Hanbury CL, Sarker A (2006) Registration of 'Ceora' grass pea. Crop Science 46, 986. 